\title{
Parenting Programs to Prevent Corporal Punishment: A Systematic Review ${ }^{1}$
}

\author{
Paolla Magioni Santini ${ }^{2}$ \\ Universidade Federal de São Carlos, \\ São Carlos-SP, Brazil
}

\author{
Lucia C. A. Williams \\ Universidade Federal de São Carlos, \\ São Carlos-SP, Brazil
}

\begin{abstract}
Studies have shown that corporal punishment against children is a common family practice, causing damage to child development. Considering that parents are the main perpetrators of this type of aggression, parenting programs are needed to raise children without violence. This study aimed at performing a systematic review of parenting programs evaluations to reduce corporal punishment. Intervention procedures, as well as design, results and limitations were identified for each study. The PRISMA protocol (Preferred Reporting Items for Systematic reviews and Meta-Analyses) was used for reporting the results. A literature survey was conducted in Brazilian databases, as well as English ones from 1994-2014. One Brazilian study and eight international studies were selected as relevant, and only four used randomized controlled trials (RCT). All studies reported satisfactory results in decreasing aggression by parents against their children. Further research in the area with solid methodology is recommended.
\end{abstract}

Keywords: parent training, psychological intervention, punishment, child abuse, family violence

\section{Programas Parentais Para a Prevenção do Castigo Corporal: Uma Revisão Sistemática}

Resumo: Estudos evidenciam que o castigo corporal contra crianças é uma prática familiar frequente e causa prejuízos ao desenvolvimento infantil. Dado que os principais autores das agressões são pais/mães, torna-se necessário o desenvolvimento de programas parentais para orientá-los a educar os filhos sem violência. O presente estudo realizou uma revisão sistemática sobre avaliações de programas parentais com conteúdo específico para redução da prática do castigo corporal. Foram identificados procedimentos de intervenção, delineamentos, resultados e limitações. Utilizou-se o protocolo PRISMA (Preferred Reporting Items for Systematic reviews and Meta-Analyses) para relatar os resultados. A revisão compreendeu bases de dados nacionais e internacionais no período de 1994-2014. Um estudo brasileiro e oito internacionais foram selecionados como relevantes, sendo que apenas quatro utilizaram ensaio clínico randomizado (RCT). Todos os estudos relataram resultado satisfatório na diminuição das agressões dos pais aos filhos. Salienta-se a necessidade da promoção de estudos na área com o devido rigor metodológico.

Palavras-chave: treinamento de pais, intervenção psicológica, punição, abuso da criança, violência na família

\section{Programas Parentales Para la Prevención del Castigo Corporal: Una Revisión Sistemática}

\begin{abstract}
Resumen: Estudios demuestran que el castigo corporal contra los niños es una práctica común y causa daños a su desarrollo. Dado que los principales perpetradores de las agresiones son padres/madres, es necesario promover programas parentales para guiarlos a criar a sus hijos sin violencia. Este estudio condujo una revisión sistemática de evaluaciones de programas parentales con contenido específico sobre la práctica de los castigos corporales. Se identificaron los procedimientos de intervención utilizados, diseños, resultados y limitaciones. Se utilizó el protocolo PRISMA (Preferred Reporting Items for Systematic reviews and Meta-Analyses) para informar de los resultados. El estudio de la literatura fue conducido en bases de datos brasileñas y e internacionales entre 1994-2014, con sólo cuatro ensayos clínicos aleatorios (ECA). Todos los estudios informaron resultados satisfactorios en la disminución de la agresión de los padres contra sus hijos. La promoción de estudios con el debido rigor metodológico en el área se hace necesaria.
\end{abstract}

Palabras clave: entrenamiento de padres, intervención psicológica, castigo, abuso de niños, violencia doméstica

\footnotetext{
${ }^{1}$ This paper is part of the first author's doctoral dissertation under supervision of the second author, presented at the Graduate Program in Psychology of the Universidade Federal de São Carlos, in 2015.

Support: São Paulo Research Foundation (FAPESP - Grant \# 2011/02431-3) and National Council for Scientific and Technological Development (CNPq - Grant \# 400943/2011-5).

${ }^{2}$ Correspondence address:

Paolla M. Santini. Laprev - Laboratório de Análise e Prevenção da Violência. Departamento de Psicologia. Universidade Federal de São Carlos. Rod. Washington Luis, km 235. CEP 13565-905. São Carlos-SP, Brazil. E-mail: paollams@gmail.com
}

Child abuse is a risk factor for healthy development, predicting many emotional, psychological, behavioral and interpersonal problems in adolescence and adulthood (Crouch, Milner, \& Thomsen, 2001; Felitti et al., 1998; Holden, 2010; Milner et al., 2010; Santini \& Williams, 2011; Straus, 2000). The use of corporal punishment aims at applying physical pain to discipline or correct a behavior considered inappropriate, and in approximately two decades was regarded as an acceptable discipline method not representative of abuse (Durrant \& Ensom, 
2012). However, recent research has found an association between a history of corporal punishment in childhood and greater risk for the occurrence of aggressive behavior, learning problems, delinquency and domestic violence in adulthood (Durrant \& Ensom, 2012; Gershoff, 2013). As a result, using corporal punishment against children is a risk factor for physical abuse and considered by experts a modality of abuse (Durrant \& Ensom, 2012; Straus, 2000).

Since several studies have shown that corporal punishment against children is a common practice in homes - usually above $50 \%$ prevalence in national and international samples (Lansford \& Deater-Deckard, 2012; Runyan et al., 2010; Straus, 2010; Zanoti-Jeronymo et al., 2009); that parents are the primary authors of aggressions (Bérgamo \& Bazon, 2011; Pinheiro \& Williams, 2009; Zanoti-Jeronymo et al., 2009); and it is considered a severe public health problem (Minayo, 2001; World Health Organization [WHO], 2014); there is a clear need for parents who use such practice to receive guidance on positive parenting to improve parental competence and cease violent disciplinary practices.

In addition, one must promote access to strategies that effectively help parents to set limits and rules for consistent discipline, enabling them to manage and prevent inappropriate behavior without restoring to violence, and contributing, thus, to a healthy relationship and development of their children (Mercy, Butchart, Rosenberg, Dahlberg, \& Harvey, 2008; Santini \& Williams, 2011). One way to promote such guidelines is through parenting programs, which are interventions designed to maximize or change parental practices through training and support with the main objective of contributing to the well-being of their children (Smith, Perou, \& Lesesne, 2002). Parenting programs are, therefore, relevant strategies for violence prevention, particularly by reducing maltreatment, and preventing the development of violent and antisocial behavior in children (Sanders \& Pidgeon, 2011).

Considering the importance of developing parenting programs that are effective for the target audience, this study aimed at conducting a systematic review of Brazilian and international literature regarding parenting programs with the specific content of reducing corporal punishment practice.

\section{Method}

The procedure to report the data from this systematic review was based on the PRISMA protocol (Preferred Reporting Items for Systematic reviews and Meta-Analyses, Liberati et al., 2009), which proposes a minimum set of evidence-based items which must be considered in studies of systematic review and meta-analysis.

The following criteria were considered to select the publications: (a) Type: Articles or book chapters; (b) Theme: Parenting programs for parents (fathers and mothers) who use corporal punishment as a method to discipline their children; (c) Period: 1994-2014; (d) Language: Portuguese or English. Databases selected from Brazil were Bireme; Google Acadêmico (Scholar); IndexPsi; Pepsic and Scielo; English ones were: Google Scholar; PsycNET (including PsycINFO and PsycARTICLES); PubMed and Web of Science. The following keywords were searched in Brazilian databases: (pais $O U$ cuidadores $O U$ família) and (programa $O U$ intervenção $O U$ capacitação) and (castigo corporal OU punição corporal $O U$ abuso fisico). The respective translations of those keywords were used in English databases: (parents OR caregivers OR family) and (program OR intervention OR training) and (corporal chastisement OR corporal punishment OR physical abuse).

All articles found in the literature search were screened by reading their titles and abstracts. The following studies were excluded: (a) with repeated occurrence; (b) other types of programs: universal prevention programs, because they are not intended to parents who use corporal punishment; tertiary prevention programs in general (children victims of abuse, unspecified) or specific ones not involving physical abuse (e.g.: sexual abuse); corporal punishment programs, but targeted to other populations (e.g.: only children, the elderly, health professionals); and (c) corporal punishment studies without description of parenting programs (e.g.: reviews, theoretical or prevalence studies, surveys, etc.).

The selected studies were read and categorized regarding their intervention procedures, design, results and limitations identified by the authors. Additionally, the effect size of the intervention (Cohen $d$ ) was analyzed considering children behavior measures used in each parental program. For studies in which the value of the effect size was not reported, the calculation was made by the authors of the present review.

\section{Results}

The resulting literature survey identified 2.555 studies (469 in Brazilian and 2.086 in English databases), as detailed in Table 1. The Google Scholar search identified more than 15.000 articles, and, thus, we selected the first 521 articles of the list, as this was the average found in the other English databases. On PsycNet, PubMed and Web of Science, as well as Google Scholar (both in Brazilian and English databases), there were no repeated studies because it is possible to insert all keywords at once in the search. After exclusions, 18 studies initially remained: one Brazilian and 17 publications in English. Among the latter, nine were repeated in other databases, so eight studies remained in this category.

Table 2 summarizes the selected intervention programs for this review. A detailed description of the instruments used in each study to evaluate program effects is beyond the scope of this revision, but, in general, the number of measures used in each program ranged from four (Santos \& Williams, 2008) to eight (Chaffin et al., 2004). The most commonly used instruments were the following: (1) The Child Behavior Checklist-CBCL (Achenbach \& Edelbrock, 1991) used in six of nine studies reviewed; (2) The Child Potential InventoryCAP (Milner, 1994), used in four studies; and (3) The Beck Depression Inventory-BDI (Beck, Steer, \& Brown, 1996); The Conflict Tactics Scale-CTS (Straus, Hamby, Finkelhor, Moore, \& Runyan, 1998); and The Trauma Symptom Checklist for Children-TSCC (Briere, 1996), used in three studies each. As the CBCL was the most used measure, Table 2 includes the identified values of the effect size of the intervention $($ Cohen $d$ ) from this instrument's scores. For studies that did not employ the CBCL, an equivalent instrument evaluating children's behavior was used for calculation. The programs 
Table 1

Brazilian and English Database Search of Articles

\begin{tabular}{|c|c|c|c|c|c|}
\hline & $\begin{array}{l}\text { Preliminary } \\
\text { results }\end{array}$ & Repeated & Other types of programs & $\begin{array}{c}\text { Not defined as } \\
\text { parenting program }\end{array}$ & Relevant \\
\hline \multicolumn{6}{|l|}{ Brazilian } \\
\hline Bireme & 64 & 21 & 26 & 17 & 0 \\
\hline IndexPsi & 14 & 6 & 0 & 8 & 0 \\
\hline Pepsic & 3 & 0 & 0 & 3 & 0 \\
\hline Scielo & 7 & 0 & 0 & 7 & 0 \\
\hline Google Acadêmico & 381 & 0 & 236 & 144 & 1 \\
\hline \multicolumn{6}{|l|}{ English } \\
\hline PsycNET & 346 & 0 & 211 & 132 & 3 \\
\hline PubMed & 468 & 0 & 309 & 156 & 3 \\
\hline Web of Science & 751 & 0 & 578 & 168 & 5 \\
\hline Google Scholar & 521 & 0 & 197 & 318 & 6 \\
\hline Total & 2,555 & 27 & 1,557 & 953 & 18 \\
\hline
\end{tabular}

Table 2

Characteristics of Parenting Programs for Corporal Punishment Prevention

\begin{tabular}{|c|c|c|c|c|c|c|c|}
\hline Author (s) & $N$ & Program & $\begin{array}{l}\text { Intervention } \\
\text { procedures }\end{array}$ & Design & Result & $\begin{array}{c}\text { Effect size } \\
\qquad(d)\end{array}$ & Limitations \\
\hline $\begin{array}{l}\text { Kolko } \\
\text { (1996) }\end{array}$ & 55 families & - & $\begin{array}{c}\text { Individual } \\
\text { psychotherapy }\end{array}$ & $\begin{array}{c}\text { RCT } \\
\text { Pre-test/Post-test } \\
\text { Follow-up: } \\
\text { 1 year }\end{array}$ & $\begin{array}{l}\text { Improvement in: child } \\
\text { to parent } \\
\text { aggression, } \\
\text { children's } \\
\text { externalizing } \\
\text { behavior, parental } \\
\text { stress, abuse risk and } \\
\text { family conflict }\end{array}$ & $\begin{array}{c}0.77^{\mathrm{b}} \\
\text { (Medium) }\end{array}$ & $\begin{array}{l}\text { Restrictions in the } \\
\text { application with } \\
\text { participants with } \\
\text { low intellectual } \\
\text { level, psychiatric } \\
\text { problems and very } \\
\text { young children }\end{array}$ \\
\hline $\begin{array}{l}\text { Kolko, } \\
\text { Iselin, } \\
\& \text { Gully } \\
\text { (2011) }\end{array}$ & 52 families & $\begin{array}{l}\text { Alternatives } \\
\text { for Families: } \\
\text { Cognitive- } \\
\text { Behavioral } \\
\text { Therapy } \\
\text { (AF-CBT) }\end{array}$ & $\begin{array}{c}\text { Individual } \\
\text { psychotherapy }\end{array}$ & Pre-test/Post-test & $\begin{array}{l}\text { Improvements in } \\
\text { parental and children } \\
\text { performance in the } \\
\text { instruments used }\end{array}$ & $\begin{array}{c}0.54^{\mathrm{b}} \\
\text { (Medium) }\end{array}$ & $\begin{array}{l}\text { Lack of evidence- } \\
\text { based methodology } \\
(\mathrm{RCT}) \text { and } \\
\text { independent } \\
\text { measures } \\
\text { (observation) }\end{array}$ \\
\hline $\begin{array}{l}\text { Borrego, } \\
\text { Urquiza, } \\
\text { Rasmus- } \\
\text { sen, \& } \\
\text { Zebell } \\
\text { (1999) }\end{array}$ & $\begin{array}{l}1 \text { mother- } \\
\text { child dyad }\end{array}$ & $\begin{array}{l}\text { Parent-Child } \\
\text { Interaction } \\
\text { Therapy } \\
\text { (PCIT) }\end{array}$ & Coaching & $\begin{array}{l}\text { Pre-test/Post-test } \\
\text { Follow-up I: } 5 \\
\text { months } \\
\text { Follow-up II: } 16 \\
\text { months }\end{array}$ & $\begin{array}{l}\text { Reduction of: child } \\
\text { behavior problems, } \\
\text { maternal and child's } \\
\text { stress and increased } \\
\text { frequency of positive } \\
\text { mother-child } \\
\text { interactions }\end{array}$ & - & $\begin{array}{l}\text { Sessions held in } \\
\text { an experimental } \\
\text { environment (no } \\
\text { guarantee of } \\
\text { generalization); } \\
\text { information with } \\
\text { siblings not } \\
\text { collected }\end{array}$ \\
\hline $\begin{array}{l}\text { Chaffin et } \\
\text { al. (2004) }\end{array}$ & $\begin{array}{l}110 \text { parent- } \\
\text { child dyads }\end{array}$ & $\begin{array}{l}\text { Parent-Child } \\
\text { Interaction } \\
\text { Therapy } \\
\text { (PCIT) }\end{array}$ & $\begin{array}{l}\text { Group } \\
\text { orientation } \\
\text { and } \\
\text { Coaching }\end{array}$ & $\begin{array}{c}\text { RCT } \\
\text { Pre-test/Post-test } \\
\text { Follow-up: } 28 \\
\text { months }\end{array}$ & $\begin{array}{l}\text { Declined frequency } \\
\text { of parent to child } \\
\text { aggressions and } \\
\text { reduction of physical } \\
\text { abuse reports }\end{array}$ & $\begin{array}{c}2.17^{\mathrm{b}} \\
\text { (Large) }\end{array}$ & $\begin{array}{l}\text { Could not control } \\
\text { the therapist } \\
\text { variable; inclusion } \\
\text { in pre-test of older } \\
\text { children who did } \\
\text { not have behavior } \\
\text { problems }\end{array}$ \\
\hline
\end{tabular}




\begin{tabular}{|c|c|c|c|c|c|c|c|}
\hline Author (s) & $N$ & Program & $\begin{array}{l}\text { Intervention } \\
\text { procedures }\end{array}$ & Design & Result & $\begin{array}{l}\text { Effect size } \\
(d)\end{array}$ & Limitations \\
\hline $\begin{array}{l}\text { Nicholson, } \\
\text { Anderson, } \\
\text { Fox, \& } \\
\text { Brenner } \\
(2002)\end{array}$ & 26 parents & STAR & $\begin{array}{c}\text { Group } \\
\text { psychotherapy }\end{array}$ & $\begin{array}{c}\text { RCT } \\
\text { Pre-test/Post-test } \\
\text { Follow-up: } \\
1 \text { month }\end{array}$ & $\begin{array}{l}\text { Significant decreased } \\
\text { levels of: verbal and } \\
\text { corporal punishment } \\
\text { against children, anger, } \\
\text { stress and reports of } \\
\text { child behavior problems }\end{array}$ & $\begin{array}{c}0.83^{\mathrm{b}} \\
\text { (Large) }\end{array}$ & $\begin{array}{c}\text { Reduced sample; } \\
\text { difficulties in } \\
\text { scheduling sessions; } \\
\text { low-return of } \\
\text { instruments } \\
\text { answered by } \\
\text { teachers }\end{array}$ \\
\hline $\begin{array}{c}\text { Santos \& } \\
\text { Williams } \\
(2008)\end{array}$ & 1 family & - & $\begin{array}{c}\text { Group } \\
\text { psychotherapy }\end{array}$ & $\begin{array}{c}\text { Pre-test/Post-test } \\
\text { Follow-up: } \\
6 \text { months }\end{array}$ & $\begin{array}{l}\text { Elimination of parent } \\
\text { to child aggression; } \\
\text { maintenance at } 24 \\
\text { week follow-up }\end{array}$ & - & $\begin{array}{l}\text { Not reported by } \\
\text { authors }\end{array}$ \\
\hline $\begin{array}{l}\text { Runyon, } \\
\text { Deblinger, } \\
\quad \& \\
\text { Schroeder } \\
\text { (2009) }\end{array}$ & $\begin{array}{l}12 \\
\text { caregivers } \\
\text { and } \\
21 \text { children }\end{array}$ & $\begin{array}{l}\text { Combined } \\
\text { Parent-Child } \\
\text { Cognitive- } \\
\text { Behavioral } \\
\text { Therapy } \\
\text { (CPC-CBT) }\end{array}$ & $\begin{array}{c}\text { Group } \\
\text { psychotherapy }\end{array}$ & Pre-test/Post-test & $\begin{array}{l}\text { General improvement } \\
\text { in emotional and } \\
\text { behavioral } \\
\text { functioning of both } \\
\text { parents and their } \\
\text { children; decreased } \\
\text { occurrence of corporal } \\
\text { punishment reports }\end{array}$ & $\begin{array}{c}1.46^{\mathrm{a}} \\
\text { (Large) }\end{array}$ & $\begin{array}{c}\text { Reduced sample } \\
\text { and lack of solid } \\
\text { methodology (RCT, } \\
\text { comparison group, } \\
\text { follow-up) }\end{array}$ \\
\hline $\begin{array}{l}\text { Kjellgren, } \\
\text { Svedin, \& } \\
\text { Nilsson } \\
(2013)\end{array}$ & 18 families & $\begin{array}{l}\text { Combined } \\
\text { Parent-Child } \\
\text { Cognitive- } \\
\text { Behavioral } \\
\text { Therapy } \\
\text { (CPC-CBT) }\end{array}$ & $\begin{array}{c}\text { Group } \\
\text { psychotherapy }\end{array}$ & Pre-test/Post-test & $\begin{array}{l}\text { Reduction of parent } \\
\text { and children's } \\
\text { depression symptoms; } \\
\text { reduction of violent } \\
\text { and inconsistent } \\
\text { parenting strategies }\end{array}$ & $\begin{array}{c}0.71^{\mathrm{a}} \\
\text { (Medium) }\end{array}$ & $\begin{array}{l}\text { Reduced sample; } \\
\text { lack of solid } \\
\text { methodology; } \\
\text { difficulties in } \\
\text { transferring an } \\
\text { American program } \\
\text { to Sweden }\end{array}$ \\
\hline $\begin{array}{l}\text { Swenson } \\
\text { et al. } \\
(2010)\end{array}$ & $\begin{array}{c}86 \\
\text { families }\end{array}$ & $\begin{array}{l}\text { Multi- } \\
\text { systemic } \\
\text { Therapy for } \\
\text { Child Abuse } \\
\text { and Neglect } \\
\text { (MST-CAN) }\end{array}$ & $\begin{array}{c}\text { Individual } \\
\text { psychotherapy }\end{array}$ & $\begin{array}{c}\text { RCT } \\
\text { Pre-test/Post-test } \\
\text { Follow-up: } \\
16 \text { months }\end{array}$ & $\begin{array}{l}\text { Declined frequency of: } \\
\text { parent to child } \\
\text { aggression and neglect; } \\
\text { improvement of health } \\
\text { symptoms in children } \\
\text { and parents }\end{array}$ & $\begin{array}{c}0.85^{\mathrm{a}} \\
\text { (Large) }\end{array}$ & $\begin{array}{c}\text { Restrictions for } \\
\text { statistical analysis } \\
\text { and generalization } \\
\text { of the results due to } \\
\text { supervision }\end{array}$ \\
\hline
\end{tabular}

Note. The effect size was calculated with the measure of the child's externalizing behavior. ${ }^{\text {a }}$ The effect size was calculated by the authors of the studies revised. ${ }^{b}$ The effect size was not available in the original study and calculated by the present authors.

are briefly described in chronological order, so that different studies analyzing the same program are illustrated in sequence.

The first program developed by Kolko (1996) for families at risk of physical abuse against children (program at the time unnamed), aimed at comparing the application of individual therapy techniques to 55 families. Participants were randomly assigned in the following intervention programs: Family Therapy (FT), Individual Child and Parent Cognitive-Behavioral Therapy (CBT) or Routine Community Services (RCS). Comparing the program phases (pre and post-test, with one year follow-up), the FT and CBT therapies were associated with specific improvements in externalizing child behavior, stress and risk of parental abuse, family conflict and decline aggression by children to parents. No differences were observed between the two therapies in consumer satisfaction or risk for abuse. According to the author, limitations involved: restrictions in application with participants with low intellectual levels, psychiatric problems and parents of very young children (age not specified).

Based on this study, the Alternatives for Families: Cognitive-Behavioral Therapy - AF-CBT was developed by Kolko, Iselin and Gully (2011). AF-CBT was evaluated in 52 families whose parents were reported to Child Protection Services (CPS), and planned in three phases: (1) engagement and psychoeducation; (2) individual skills building; (3) family applications. The first phase accessed the roles and interactions in the family: family members were guided to deal with thoughts associated with guilt; the negative effects of using violence were reviewed; and a family contract was established as an agreement of non-use of violence. The next phase aimed 
at training specific problem solving and communication skills. In the final stage, familiar routines as alternatives to the use of violent conflict resolution were established. Results showed better performance of parents and children in instrument scores when comparing pre and post-test (children: externalizing behavior; parents: anger, anxiety, social competence), and better social interaction among peers; child's adjustment in connection with security and reduced fear/sadness. Reported limitations involved a lack of solid methodology (e.g. did not use RCT), and lack of independent measures, as only verbal measures were employed and not observational sessions of parent-child interactions.

The study of Borrego, Urquiza, Rasmussen e Zebell (1999) was the first to adapt the Parent-Child Interaction Therapy (PCIT) program with a specific content regarding corporal punishment. The PCIT was originally idealized by Capage, McNeil, Foote and Eyberg (1998), and used as an intervention procedure the observation of parent/caregiver and child interaction while the therapist was behind a twoway mirror. In these sessions, the parent used a bug-in-the ear device from where immediate orientations on how to interact with the child were received - a technique called coaching. Borrego et al. (1999) followed such PCIT methodology with only one mother-child dyad. Results indicated a reduction of child behavior problems, and mother and child's stress, as well as increased frequency of positive mother-child interactions, comparing pre and post-test, with a 5 month follow-up, followed by another one at 16 months. The authors reported that the sessions conducted in an experimental environment may have been a limitation, as the absence of sessions in the natural environment might not ensure generalization. In addition, data were not collected with siblings of the target child, which would have been another measure of generalization.

Still using the PCIT approach, Chaffin et al. (2004) conducted a large study aimed at evaluating the efficacy of PCIT in reducing the reoccurrence of reports with 110 parents who had previously been reported to authorities as using corporal punishment. The study compared three types of intervention: (a) PCIT; (b) PCIT plus individualized enhanced services; and (c) a standard community-based parenting group. Parents were randomly assigned among the different modalities, and attended motivational group sessions prior to the coaching sessions. The difference between the first and second version of PCIT resided in additional individualized services in cases of depression, alcohol/drug abuse and violence against woman. After the follow-up of approximately 28 months, $19 \%$ of PCIT participants relapsed in corporal punishment reports, a lower frequency compared to the standard parental group participants (49\%). There were no significant differences when comparing pre and post-test results of PCIT and PCIT plus individualized enhanced services. The main limitation of the study referred by the authors involved not controlling the 'therapist' variable, as the therapists of PCIT and PCIT plus individualized enhanced services were the same, whereas the community group had different therapists. Another mentioned limitation referred to the selection of older children who did not have behavior problems in the pre-test, rendering the evaluation of pre and post-test irrelevant.

Nicholson, Anderson, Fox and Brenner (2002) evaluated the efficacy of a program with parents of young at-risk children. They defined "at-risk" as excessive use of verbal abuse and corporal punishment by parents from low socioeconomic status. Such program was originally developed by Fox and Fox (1992) and called STAR. It was divided into four phases: (1) strategies in dealing with anger and parental stress when faced with difficult children behaviors; (2) providing information to parents about child development phases; (3) orientation about positive parenting practices (e.g. the importance of affection, the use of differential reinforcement); and (4) guidance regarding disciplinary practices (e.g. setting limits and rules; timeout). 26 parents of $1-5$ year old children participated in the Nicholson et al. (2002) study, and the group sessions (comprising of a maximum of four members) lasted $1 \mathrm{~h} 30 \mathrm{~m}$ over 10 weeks. The study used RCT and the results indicated significant decreases of verbal abuse and corporal punishment against children; anger; stress; and reports of child behavior problems when compared to the control group. Such results were maintained at follow-up (1 month). Limitations discussed by the authors involved the restricted sample size, making it difficult to generalize the data; the challenge of adapting schedules and appointments with parents; and the low return rate of the instruments required to be answered by teachers.

The Brazilian study by Santos and Williams (2008) was aimed at reducing physically aggressive parental behaviors towards their children. Three families whose parents had repeated reports to CPS of using physical violence were initially selected. However, because one mother moved to another city and another mother who was pregnant delivered her baby, only one family completed the intervention. Such family lived in poverty (earned only one Brazilian minimum wage), the father was physically handicapped and the mother had mental deficiency. Two children were under their care: a girl (10 years old) who was also mentally handicapped and a boy ( 8 years old) with behavioral problems who was the target of parental aggression. 26 weekly meetings were held with both parents in which relaxation techniques were applied, in addition to: strategies to foster self-control, social skills, social-problem solving, anger management; as well as modeling and role-playing of positive parentchild interactions. Parental and the target child's self-reports were taken on weekly basis regarding possible aggressions; interviews and teacher assessments about the target child's behavior; and case monitoring at Child Protection. Results indicated the elimination of parental aggressive behavior towards the child at post-test for all informants (parents, child, teachers and CPS), and this was maintained at a six month follow-up. The authors argue that such favorable result may be explained in terms of successful engagement strategies, but they do not point out the study's limitations.

Runyon, Deblinger and Schroeder (2009) conducted a pilot-study intervention to parents at risk of physically abusing their children, called Combined Parent-Child Cognitive-Behavioral Therapy - CPC-CBT. This program 
encompasses three phases: intervention with parents (first individually and subsequently in groups); likewise individual and group intervention with children; group intervention with parents and children together. The components covered in the sessions include: development of parenting skills; and analyzing parenting deficits and unrealistic expectations of their children. A procedure to maximize adhesion was planned, providing support for parents and children. In addition, the CPC-CBT aimed at involving the entire family in the training, and not only the parents or the target child. Other differential topics, according to the authors, involved strategies focusing on helping the child overcome Posttraumatic Stress Disorder (PTSD), depression and dysfunctional beliefs associated with physical abuse. 12 parents and 21 children participated in a group psychotherapy format over 16 weeks. The data showed overall improvement in emotional and behavioral functioning of both parents and children, as well as a decrease of recurrence of corporal punishment reports by parents and children, comparing pre and post-test. In joint parent-child sessions, an improvement in the behavioral repertoire of children in talking to their parents about their history corporal punishment was observed, encouraging parents in their sharing efforts to improve. In addition, there was an improvement in parental perception of internalizing and externalizing behavior of children. The small sample size and the lack of solid methodology (did not use RCT, control groups or follow-up) were cited as limitations, but the authors stressed that it was a pilot study.

Following the CPC-CBT model proposed by Runyon et al. (2009), Kjellgren, Svedin e Nilsson (2013) evaluated, also in a pilot study, the results of a psychotherapeutic treatment to Swedish parents with a history of physically abusing their children. Participants were 18 families (26 adults and 25 children) and the intervention lasted 16 sessions. When comparing pre and post-tests, results indicated a significant decrease in symptoms of parental and child depression; reduced physically abusive and inconsistent parenting practices; and decreased PTSD symptoms in children who reported lower frequency of violence by parents. In addition, there was an increase in the use of positive parenting strategies after completing the treatment. Study limitations highlighted by the authors were related to the small sample size, lack of solid methodology (did not use RCT, control group or follow-up), and difficulties in transferring an American program to the Swedish culture, mainly because of physical abuse definition and the level of tolerance of such a practice (Sweden has zero tolerance to the use of corporal punishment, while the US has some degree of tolerance for this practice).

Finally, Swenson, Schaeffer, Henggeler, Faldowski and Mayhew (2010) assessed an application of the Multisystemic Therapy for Child Abuse and Neglect (MST-CAN) in families monitored by CPS due to child physical abuse. This study was a variation of the Multisystemic Therapy (MST) designed by Henggeler, Schoenwald, Borduin, Rowland and Cunningham (2009), and intended for the prevention and treatment of antisocial behavior in youngsters. Overall, the MST has as principle participants' assistance in the community, whether at home, school or other sites. The therapy lasts 60 hours and therapists seek to make the family develop a social support network in the community and remove obstacles (such as the abuse of alcohol/drugs, the need for medication in mental health problems) to maximize parental functioning. In its adaptation, MST-CAN includes actions such as: (a) a plan developed and signed by the family about what to do in situations where some members feel in danger; (b) work in partnership with CPS when the case is under their supervision; (c) parental cognitive restructuring; (d) specific cognitive-behavioral techniques to use in conflict situations, such as anger management; problem solving; proper communication (without psychological abuse); and (e) parents with PTSD symptoms could have specific psychotherapy sessions.

The MST-CAN results described by Swenson et al. (2010) showed significant improvement in the scores of instruments applied when comparing pre and post-tests, decreasing symptoms of mental health problems in both children and parents, as well as a substantial reduction in parental neglect and severe use of aggression. Such positive results are justified by the authors in terms of the quality of service (trained professionals), and the fact that the service location was inserted in the family community. Limitations of the study discussed by the authors relate mainly to restrictions for statistical analysis (risk for Type I and Type II Errors); the exclusive use of parental verbal reports on the measures, and the fact that the program developer also was co-supervisor, which would limit the generalizability of results.

\section{Discussion}

Results from the programs here reviewed have shown that the use of corporal punishment to children may be changed through specific interventions based on parenting programs geared towards teaching how to raise children without the use of violence. These programs included teaching parents about positive discipline and child behavior management techniques, associated with monitoring parental performance by specialists when needed, components that may have contributed to parental improvement.

With regards to the intervention procedures, three of nine studies used individual psychotherapy (Kolko, 1996; Kolko et al., 2011; Swenson et al., 2010); four used group psychotherapy (Kjellgren et al., 2013; Nicholson et al., 2002; Runyon et al., 2009; Santos \& Williams, 2008); one used coaching (Borrego et al., 1999); and Chaffin et al. (2004) used a motivational orientation in the initial phase, followed by coaching. Among the nine studies, four have used a RCT design with pre-test/post-test (Chaffin et al., 2004; Kolko, 1996; Nicholson et al., 2002; Swenson et al., 2010); and the remaining used a pre-test/post-test design on the treatment group only (without a comparison group). Six of nine studies have conducted follow-up evaluations, and the period between post-test and follow-up ranged from 1 month (Nicholson et al., 2002) to 2 years (Chaffin et al., 2004). Although there is no rule about the appropriate length of time for follow-up, as this depends on many factors (Weiner, Schinka, \& Velicer, 2012), we argue that, in general, longer periods (about six months) would 
be more reliable to identify the intervention maintenance over time. Thus, the period of one month for follow-up used on the Nicholson et al. study seems to be short.

Despite the differences between procedures and designs, all studies have achieved satisfactory results in the reduction of aggression by parents against their children, and the majority reported a decrease of children's behavioral problems, as well as a decrease of emotional problems from parents and children. Only two studies (Borrego et al., 1999; Santos \& Williams, 2008) could not have the effect size analysis conducted, as the authors did not offer sufficient quantitative data. Coincidentally, these two studies employ only 2-3 participants, featuring a casestudy format. Among the methodologically robust interventions, considering the variable "externalizing behavior of the child", the effects varied from 0.54 (medium effect) to 2.17 (large effect), indicating not only the potential of the intervention to produce positive changes in the post-test, but that the programs seemed to be consolidated. The study with the highest value of effect size was by Chaffin et al. (2004), suggesting that the intervention procedures used (motivational orientation associated with coaching) combined with solid methodology (large sample, RCT, follow-up of 28 months and the use of eight instruments for evaluation) were key elements in obtaining the positive effects.

A Cognitive-behavioral approach (and derived techniques) was used in all studies reviewed here, except for the study Swenson et al. (2010), which used a multi-system approach. Kolko (1996) argues that the Cognitive-behavioral approach proves to be more effective than others in reducing the level of parental aggression and use of corporal punishment, and the results observed in this review reinforce this position.

All studies, with exception for Santos and Williams (2008), identified honest limitations, emphasizing self-criticism regarding reduced sample of participants and the lack of solid methodology. As a way to improve the area, the programs would have to refine their methodology, using RCT, followup assessments over long periods, as well as observational measures examined by independent judges to reduce the risk of bias of self-reported measures to consolidate them as evidencebased programs.

In addition, the difficulties of conducting and assessing interventions with parents who use corporal punishment to discipline their children must be stressed. Besides involving atrisk groups (parents living in poverty, with several mental health problems), the decision to accept taking part of a treatment program for the aggressive behavior against their children is a complex one, and possibly one of the challenges in recruiting participants. The engagement of such parents until the end of treatment requires much effort, patience and flexibility from the intervention team (Runyon et al., 2009). Studies whose services where offered in the community seemed to be more likely to retain participants (Kolko et al., 2011; Swenson et al., 2010), although such strategy is costly and not easily achievable.

There are some limitations of this review that should be considered. The data analysis and data extraction were not carried out by independent judges. Furthermore, the heterogeneity in the terminology of the area imposed challenges to the literature search. In general, there were more studies with the physical abuse keyword compared to the keywords corporal punishment and corporal chastisement. In addition, the use of the keyword physical abuse allowed for the inclusion of studies related to drug and sexual abuse, hindering the selection of relevant articles. Thus, papers with keywords sexual and drug/drugs were excluded, whenever such filter search option was available. Another difficulty involved separating intervention studies on abuse in general from those specific on corporal punishment. In such cases, the description of participant characteristics and focus of the study were carefully analyzed. Nevertheless, although detailed search efforts were made following specific criteria, it is possible that relevant studies may have not been included in the present review.

Regarding the characteristics of the parenting programs detailed in this review with specific content in reducing corporal punishment against children, it seems that intervention procedures involving individual or group psychotherapy should be associated with coaching, as proposed by Chaffin et al. (2004). It would also seem advisable to add to the intervention the videofeedback procedure, in which parentchild interactions are recorded and subsequently presented to parents in the video format, indicating their appropriate behaviors and those still in need of improvement. This procedure is commonly used in interventions with families, as identified by Fukkink (2008) in a meta-analysis of family programs in general with the use of videofeedback, indicating that the use of videofeedback contributes significantly to the improvement of parental behavior. Compared to a parental program that uses only psychotherapy, the same program associated with videofeedback could present better results in parental behavior, according to Phaneuf and McIntyre (2007). In addition, we emphasize that the program should contain a Manual with guidelines, so that it is structured and favorable of replication.

Future research may identify factors that contribute to the engagement in prevention programs of parents who abuse their children. Professionals working in the frontline with victimized children or with abusive parents could act in collaboration with researchers from this field, joining efforts in improvement of objective assessments with sound methodology.

This review identified only one Brazilian study published in the last 20 years regarding an evaluation of an intervention to parents who use corporal punishment (Santos \& Williams, 2008). Although this study is modest from a methodological point of view, its relevance relies in involving a high-risk family: a couple with multiple disabilities, with repeated reports to Child Protection for using physical violence to their son. There is a gap in the Brazilian literature in this area, notably because this country has recently approved a Federal Law (Brazil, 2014), to ban corporal punishment against children in its vast territory.

Corporal punishment is commonly employed by parents around the world, however it seems there are only a few published studies describing effective parenting programs to reduce this behavior. Overall, the results presented in this review are encouraging about the applicability and positive effects of the intervention programs focused on corporal punishment. However, due to the limited number of studies 
found, there is a clear need to develop more research with solid methodology in order to promote further investigations on the application, utility and cost-effectiveness of the various intervention alternatives, to ensure that the investments made in treatment and prevention may show the desired return, as suggested by Bruns et al. (2008).

\section{References}

Achenbach, T. M., \& Edelbrock, C. S. (1991). Manual for the Child Behavior Checklist and revised child behavior profile. Burlington, VT: University of Vermont.

Beck, A. T., Steer, R. A., \& Brown, G. K. (1996). Manual for the Beck Depression Inventory (2nd ed.). San Antonio, TX: Psychological Corporation.

Bérgamo, L. P. D., \& Bazon, M. R. (2011). Experiências infantis e risco de abuso físico: Mecanismos envolvidos na repetição da violência [Child's experiences and risk of physical abuse: Mechanisms involved in repeating violence]. Psicologia: Reflexão e Crítica, 24(4), 710-719. doi:10.1590/S0102-79722011000400011

Borrego, J., Jr., Urquiza, A. J., Rasmussen, R. A., \& Zebell, N. (1999). Parent-child interaction therapy with a family at high risk for physical abuse. Child Maltreatment, 4(4), 331-342. doi:10.1177/1077559599004004006

Brazil (2014). Lei Menino Bernardo [Menino Bernardo's Act] No. 13.010, banning corporal punishment and cruel and degrading treatment of children. Retrieved from http:// www.planalto.gov.br/ccivil_03/_Ato2011-2014/2014/ Lei/L13010.htm

Briere, J. (1996). Trauma Symptom Checklist for Children (TSCC) professional manual. Odessa, FL: Psychological Assessment Resources.

Bruns, E. J., Hoagwood, K. E., Rivard, J. C., Wotring, J., Marsenich, L., \& Carter, B. (2008). State implementation of evidence-based practice for youths, part II: Recommendations for research and policy. Journal of the American Academy for Child and Adolescent Psychiatry, 47(5), 499-504. doi:10.1097/CHI.0b013e3181684557

Capage, L. C., McNeil, C. B., Foote, R., \& Eyberg, S. M. (1998). Parent-child interaction therapy: An effective treatment for young children with conduct problems. The Behavior Therapist, 21, 137-138.

Chaffin, M., Silovsky, J. F., Funderburk, B., Valle, L. A., Bristan, E. V., Balachova, T., . . . Bonner, B. L. (2004). Parent-child interaction therapy with physically abusive parents: Efficacy for reducing future abuse reports. Journal of Consulting and Clinical Psychology, 72(3), 500-510. doi:10.1037/0022-006X.72.3.500

Crouch, J. L., Milner, J. S., \& Thomsen, C. (2001). Childhood physical abuse, early social support and risk for maltreatment: Current social support as a mediator of risk for child physical abuse. Child Abuse \& Neglect, 25(1), 93-107. doi:10.1016/S0145-2134(00)00230-1

Durrant, J., \& Ensom, R. (2012). Physical punishment of children: Lessons from 20 years of research. Canadian Medical Association Journal, 184(12), 1373-1377. doi:10.1503/cmaj.101314

Felitti, V. J., Anda, R. F., Nordenberg, D., Williamson, D. F., Spitz, A. M., Edwards, V., . . . Marks, J. S. (1998). Relationship of childhood abuse and household dysfunction to many of the leading causes of death in adults: The Adverse Childhood Experiences (ACE) study. American Journal of Preventive Medicine, 14(4), 245258. doi:10.1016/S0749-3797(98)00017-8

Fox, R. A., \& Fox, T. A. (1992). Leader's guide: STAR parenting program. Bellevue, WA: STAR Parenting.

Fukkink, R. G. (2008). Video feedback in widescreen: A meta-analysis of family programs. Clinical Psychology Review, 28(6), 904-916. doi:10.1016/j.cpr.2008.01.003

Gershoff, E. T. (2013). Spanking and child development: We know enough now to stop hitting our children. Child Development Perspectives, 7(3), 133-137. doi:10.1111/ cdep. 12038

Henggeler, S. W., Schoenwald, S. K., Borduin, C. M., Rowland, M. D., \& Cunningham, P. B. (2009). Multisystemic therapy for antisocial behavior in children and adolescents (2nd ed.). New York, NY: Guilford.

Holden, G. W. (2010). Parenting: A dynamic perspective. Thousand Oaks, CA: Sage.

Kjellgren, C., Svedin, C. G., \& Nilsson, D. (2013). Child physical abuse: Experiences of combined treatment for children and their parents: A pilot study. Child Care in Practice, 19(3), 275-290. doi:10.1080/13575279.2013.7 85934

Kolko, D. J. (1996). Individual cognitive-behavioral treatment and family therapy for physically abused children and their offending parents: A comparison of clinical outcomes. Child Maltreatment, 1(4), 322-342. doi:10.1177/1077559596001004004

Kolko, D. J., Iselin, A.-M. R., \& Gully, K. J. (2011). Evaluation of the sustainability and clinical outcome of Alternatives for Families: Cognitive-Behavioral Therapy (AF-CBT) in a child protection center. Child Abuse \& Neglect, 35(2), 105-116. doi:10.1016/j.chiabu.2010.09.004

Lansford, J. E., \& Deater-Deckard, K. (2012). Childrearing discipline and violence in developing countries. Child Development, $\quad 83(1), \quad 62-75 . \quad$ doi:10.1111/j.14678624.2011.01676.x

Liberati, A., Altman, D. G., Tetzlaff, J., Mulrow, C., Gøtzsche, P. C., Ioannidis, J. P., . . Moher, D. (2009). The PRISMA statement for reporting systematic reviews and metaanalyses of studies that evaluate health care interventions: Explanation and elaboration. PloS Medicine, 6(7), e1000100. doi:10.1371/journal.pmed.1000100

Mercy, J. A., Butchart, A., Rosenberg, M. L., Dahlberg, L., \& Harvey, A. (2008). Preventing violence in developing countries: A framework for action. International Journal of Injury Control and Safety Promotion, 15(4), 197-208. doi:10.1080/17457300802406955

Milner, J. S. (1994). Assessing physical child abuse risk: The child abuse potential inventory. Clinical Psychology Review, 14(6), 547-583. doi:10.1016/02727358(94)90017-5 
Milner, J. S., Thomsen, C. J., Crouch, J. L., Rabenhorst, M. M., Martens, P. M., Dyslin, C. W., ... Merrill, L. L. (2010). Do trauma symptoms mediate the relationship between childhood physical abuse and adult child abuse risk? Child Abuse \& Neglect, 34(5), 332-334. doi:10.1016/j. chiabu.2009.09.017

Minayo, M. C. S. (2001). Violência contra crianças e adolescentes: Questão social, questão de saúde [Violence against children and adolescents: Social issue, health issue]. Revista Brasileira de Saúde Materno Infantil, 1(2), 91-101. doi:10.1590/S1519-38292001000200002

Nicholson, B., Anderson, M., Fox, R., \& Brenner, V. (2002). One family at a time: A prevention program for at-risk parents. Journal of Counseling \& Development, 80(3), 362-371. doi:10.1002/j.1556-6678.2002.tb00201.x

Phaneuf, L., \& McIntyre, L. L. (2007). Effects of individualized video feedback combined with group parenting training on inappropriate maternal behavior. Journal of Applied Behavior Analysis, 40(4), 737-741. doi:10.1901/jaba.2007.737-741

Pinheiro, F. M. F., \& Williams, L. C. A. (2009). Violência intrafamiliar e intimidação entre colegas no ensino fundamental [Family violence and bullying in primary school]. Cadernos de Pesquisa, 39(138), 995-1018. doi:10.1590/S0100-15742009000300015

Runyan, D. K., Shankar, V., Hassan, F., Hunter, W. M., Jain, D., Paula, C. S., . . Bordin, I. A. (2010). International variations in harsh child discipline. Pediatrics, 126(3), e701-e711. doi:10.1542/peds.2008-2374

Runyon, M. K., Deblinger, E., \& Schroeder, C. M. (2009). Pilot evaluation of outcomes of combined parent-child cognitive-behavioral group therapy for families at risk for child physical abuse. Cognitive and Behavioral Practice, 16(1), 101-118. doi:10.1016/j.cbpra.2008.09.006

Sanders, M., \& Pidgeon, A. (2011). The role of parenting programmes in the prevention of child maltreatment. The Australian Psychologist, 46(4), 199-209. doi:10.1111/ j.1742-9544.2010.00012.x

Santos, G. E., \& Williams, L. C. A. (2008). Prevenção terciária de problemas de comportamento infantil: Intervenção com pais que maltratam [Tertiary prevention of child behavior problems: Intervention with abusive parents]. In E. G. Mendes, M. A. Almeida, \& M. C. P. I. Hayashi (Eds.), Temas em educação especial: Conhecimentos para fundamentar a prática [Special education themes: Knowledge to support the practice] (pp. 213-226). Araraquara, SP: Junqueira \& Marin/CAPES PROESP.

Santini, P. M., \& Williams, L. C. A. (2011). Castigo corporal contra crianças: O que podemos fazer para mudar essa realidade? [Corporal punishment against children: What can we do to change this reality?] In C. V. B. B. Pessoa, C. E. Costa, \& M. F. Benvenuti (Eds.), Comportamento em foco [Behavior at issue] (Vol. I, pp. 603-612). São Paulo, SP: ABPMC.

Smith, C., Perou, R., \& Lesesne, C. (2002). Parent education. In M. H. Bornstein (Ed.), Handbook of parenting: Vol. 4. Social condition and applied parenting (pp. 389-410).
Mahwah, NJ: Lawrence Erlbaum.

Straus, M. A. (2000). Corporal punishment and primary prevention of physical abuse. Child Abuse \& Neglect, 24(9), 1109-1114. doi:10.1016/S0145-2134(00)00180-0

Straus, M. A. (2010). Prevalence, societal causes, and trends in corporal punishment by parents in world perspective. Law and Contemporary Problems, 73(2), 1-30. Retrieved from http://scholarship.law.duke.edu/cgi/viewcontent. cgi? article $=1564 \&$ context $=$ lcp

Straus, M. A., Hamby, S. L., Finkelhor, D., Moore, D. W., \& Runyan, D. (1998). Identification of child maltreatment with the Parent-Child Conflict Tactics Scales: Development and psychometric data for a national sample of American parents. Child Abuse and Neglect, 22(4), 249-270. doi:10.1016/S0145-2134(97)00174-9

Swenson, C. C., Schaeffer, C. M., Henggeler, S. W., Faldowski, R., \& Mayhew, A. M. (2010). Multisystemic therapy for child abuse and neglect: A randomized effectiveness trial. Journal of Family Psychology, 24(4), 497-507. doi:10.1037/a0020324

Weiner, I. B., Schinka, J. A., \& Velicer, W. F. (2012). Handbook of psychology: Vol. 2. Research methods in psychology (2nd ed.). New York, NY: John Wiley \& Sons.

World Health Organization. (2014). Child maltreatment (Fact sheet no. 150). Retrieved from http://www.who.int/ mediacentre/factsheets/fs150/en/

Zanoti-Jeronymo, D. V., Zaleski, M., Pinsky, I., Caetano, R., Figlie, N. B., \& Laranjeira, R. (2009). Prevalência de abuso físico na infância e exposição à violência parental em uma amostra brasileira [Prevalence of physical abuse in childhood and exposure to parental violence in a Brazilian sample]. Cadernos de Saúde Pública, 25(11), 2467-2479. doi:10.1590/S0102-311X2009001100016

Paolla Magioni Santini holds a Ph.D. in Psychology from Universidade Federal de São Carlos.

Lucia C. A. Williams is a Professor of Psychology at the Universidade Federal de São Carlos.

Received: Nov. 7, 2014

1st Revision: Apr. 26, 2015

Approved: July 27, 2015

How to cite this article:

Santini, P. M., \& Williams, L. C. A. (2016). Parenting programs to prevent corporal punishment: A systematic review. Paidéia (Ribeirão Preto), 26(63), 121-129. doi:10.1590/1982-43272663201614 